Abstracta Iranica Abstracta Iranica

Revue bibliographique pour le domaine irano-aryen

Volume 23 | 2002

Comptes rendus des publications de $\mathbf{2 0 0 0}$

\title{
« Hierarchical image and reality: The construction of a tribal chiefship ». Comparative Studies in Society and History, vol. 42, $\mathrm{n}^{\circ}$ 1, 2000, pp. 49-66.
}

Jean-Pierre Digard

\section{OpenEdition}

Journals

Édition électronique

URL : http://journals.openedition.org/abstractairanica/35708

DOI : 10.4000/abstractairanica.35708

ISSN : 1961-960X

Éditeur :

CNRS (UMR 7528 Mondes iraniens et indiens), Éditions de l'IFRI

Édition imprimée

Date de publication : 15 mai 2002

ISSN : 0240-8910

Référence électronique

Jean-Pierre Digard, « « Hierarchical image and reality: The construction of a tribal chiefship ».

Comparative Studies in Society and History, vol. 42, $n^{\circ} 1,2000$, pp. 49-66. », Abstracta Iranica [En ligne],

Volume 23 | 2002, document 375, mis en ligne le 08 février 2010, consulté le 25 septembre 2020.

URL : http://journals.openedition.org/abstractairanica/35708; DOI : https://doi.org/10.4000/

abstractairanica.35708

Ce document a été généré automatiquement le 25 septembre 2020.

Tous droits réservés 


\title{
« Hierarchical image and reality: The construction of a tribal chiefship ». Comparative Studies in Society and History, vol. $42, \mathrm{n}^{\circ} 1,2000$, pp. 49-66.
}

\author{
Jean-Pierre Digard
}

1 Se livrant à son tour à l'un des rites de l'anthropologie nord-américaine 泡 qui consiste à procéder à la nième relecture critique de l'ouvrage Nomads of South Persia (1960) de Fredrik Barth 㜯, l'A. reproche au père des études ethnologiques modernes sur les tribus iraniennes d'avoir donné du chef tribal une image autocratique, d'avoir surestimé son pouvoir et minoré le contrôle qu'exercent sur lui les membres de la tribu. Comparant le cas des Bāṣerī à la situation dans d'autres tribus de la région, l'A. suggère de réinterpréter l'autorité du chef tribal en termes de "gestion d'image" dans un contexte politique particulier.

Outre qu'on finit à la longue par se lasser de ce meurtre du père sans cesse répété, on ne peut s'empêcher de se demander si ce que Salzman compare ici est bien comparable : quelle est en effet la légitimité de sa critique de Barth, dans la mesure où, pour autant que l'on sache, Salzman étudiait les Balūč dans les années 1970, et non les Bāṣerī dans les années 1950 ? Pourquoi ce que Salzman a trouvé dans le Balūčestān (et éventuellement d'autres aussi ailleurs) devrait autoriser une remise en cause de ce que Barth a trouvé vingt ans auparavant dans le Fārs ? Enfin, n'est-il pas plus productif, à ce niveau de la réalité, de scruter des écarts dans le temps et dans l'espace, que d'essayer de plaquer toujours et partout un même concept, au demeurant extrêmement flou? 
INDEX

Thèmes : 16.1. Iran

\section{AUTEURS}

JEAN-PIERRE DIGARD

CNRS - Paris 